\title{
The Future of College and
}

\section{Research Libraries}

In this address the author relates the future of college and research libraries to the changing role of academic librarians, the assistance technology may give, and the political activity required to secure government aid. A general view of higher education's future indicates that education should relate more effectively to individual development; to individual coping and work and the development of the free self; and to the enveloping polity. Each of these factors has relevance as well for the future of academic libraries.

I

HAVE BEEN ASKED TODAY to say a word or two about the future of higher education generally and about the future of college and research libraries specifically. I do this with the normal trepidations of the appointed seer. I share David Riesman's view that "the possibilities of historical discontinuity" are so strong that most of us are likely to prove very poor prophets indeed.

It is true that, barring catastrophe, there are demographic certainties ahead-for example, a startling reduction in-the number of eighteen-year-olds over the next decade - that have profound implications for higher education. It is also probable that the contemporary headaches of complexity, of interdependency, of trade-offs will not disappear. As Joe Nyquist, New York's former commissioner of education, is fond of saying, "If Moses were to come down from the mountain today, the two tablets would be aspirin!" But little else is really predictable in any precise sense.

Stephen K. Bailey is professor of education and social policy, Harvard University, Cambridge, Massachusetts. This article is based upon an address delivered at a meeting of the Association of College and Research Libraries on June 18, 1977, in Detroit during the Annual Conference of the American Library Association. At that time the author was acting president, American Council on Education.

\section{THINKING OF THE FUTURE}

Why, then, do we speculate about the future? Surely, the only sensible answer is that we speculate about the future because such an exercise helps us to think normatively about the present. We can do nothing about the past except to rearrange its messages and try to internalize its lessons. But thoughts of the future should enable us, by extrapolating what we presently observe and experience, to judge whether such projections leave us buoyant and hopeful or sullen and dejected.

Harlan Cleveland once wrote that "futurists analyze what might happen later to illuminate what should happen earlier." We focus on the 1980s in order to entertain the possibilities of corrective action in the remaining years of the 1970 s.

Let me address myself, first of all, to your own future-to the future of college and research libraries.

All of you must have been subjected in recent years to an endless montage of future scenarios about libraries. I have only caught glimpses of these out of the corner of my eye. Beginning ten or fifteen years ago, speeches and articles began to appear predicting the imminent demise of libraries as we have known them. Computers would replace card catalogs, microfiche and a variety of electronic print-out systems would 
replace books and journals. Interlibrary loans would be superseded by instantaneous facsimile transfers. Computer terminals would replace librarians. You know the litany far better than I do. Patently, the revolution has not happened.

The real world is something else again: technology addressed, not to automated information retrieval, but to antipilfering devices; excessive adrenalin caused by staff shortages, diminishing budgets, escalating costs of books and serials; new pressures away from the printed word toward sound and pictures.

And these on top of what Sandburg called "the known solemn repetitions of history" - the controversies over divisional, disciplinary, or professional branch libraries; the arguments over whether librarians or faculty or administrators should determine expenditures of library money; the periodic breakdown of the system from a variety of overloads; handling the dissonances of personal chemistry and temperament among the staff; struggling for a decent recognition and decent recompense in social systems where librarians are frequently viewed as faceless drones.

I am sure I have missed some issues of even greater importance to you. But my purpose is not to map your anxieties, it is only to suggest that most of what occupies most of your waking attention is light-years away from what most of you were taught in graduate school. This is not to denigrate the value of what you did learn. It is only to suggest that the higher you go in your work, the more you will become, not superlibrarians, but supermanagers-society's great orchestrators of complexity.

\section{THE FUTURE OF LIBRARIANS}

I cannot really tell you about the future of libraries. But I think I can tell you something about the future of librarians. Melancholy as it may sound to some of you, librarians of the future must be budgeteers and systems managers, and conflict resolvers, and priority selectors, and superb academic politicians. They must be negotiators and compromisers and "Dear Abbies" and policemen. I know this, because what I have just said characterizes what the most successful of you are or do at present. You are involved in one of the most complex management areas known to humankind.

If I am even halfway correct, it is possible that you must ask yourselves whether the preservice and in-service professional education available to librarians is really adequate or even totally appropriate. It may be useful for you to seek out those in the management and behavioral sciences who are concerned with developing administrative rather than bibliothecal arts and skills.

The health of college and research libraries in the future will depend far more on your management abilities than upon your knowledge of accessions, cataloging procedures, and rare books. Most of you are aware of this, but I doubt that your professional training reflects your visceral and experiential sophistication.

\section{TECHNOLOGY}

New technology is bound to change libraries incrementally. But the process will be infinitely slower than the bright-eyed and bushy-tailed electronics-oriented reformers predict. The human imagination can now conceive of complete and interlocking systems. But the economics and logistics of such wholesale transformations are formidable indeed.

Furthermore, there are significant outer limits to the utility of elaborate systems. All of them tend to falter at the point where important scholarly work is pressing the frontiers of new knowledge. The very nature of creative intellectual work is to raise unprecedented questions. Unprecedented questions are the enemy of existing search and retrieval systems. Retrieval wisdom is conventional wisdom. The business of the mind is unconventional wisdom; and although new knowledge stands on the shoulders of the old, it is not a simple extension of the existing corpus of facts and analysis.

\section{GOVERNMENT AID AND LIBRARY COSTS}

But I am infringing upon my concluding remarks about the future of higher education generally. And before I turn to my concluding peroration, I do want to remind you that your friends in Washington need your help. Perhaps it is enough to underscore that Title II (the college library resources section) of Public Law 89-329 Part 
$\mathrm{A}$ is authorized to $\$ 80.5$ million. Effective appropriations under that law are running at a tenth of that authorized figure. The American Council on Education is working with other associations in trying to move the appropriated figure upward. Legislators seem to have a hard time understanding that the average price of a science book has increased 38 percent in three years; that in the same period the average cost of a sociology or economics text has risen from $\$ 12.27$ to $\$ 20.03$, an increase of 64 percent. Federal appropriations for college library resources have diminished about 20 percent during the same three-year period-and this at a time when libraries must deal with new demands, new clienteles, and new restrictions on photocopying.

What is true of PL 89-329 Part A is also true of Parts B and C-for library training and research and for research libraries. Part $\mathrm{B}$ is authorized at $\$ 35.5$ million. Current appropriations are running at $\$ 3$ million. Part C is authorized at $\$ 15$ million. Amounts appropriated to date: zero. And all this in the face of the reality that the average cost of U.S. periodical subscriptions has increased 180 percent since 1967 and that the price of foreign books and journals is going out of sight.

Unless you people understand the importance of political activity on behalf of your basic interests, your future will be grim indeed. It takes no science of prophecy to make that prediction.

\section{FUTURE OF AMERICAN HIGHER EDUCATION}

Let me turn finally to an attempt to put your future in the larger context of the future of American higher education. What is ahead for the colleges and universities of which you are such an essential part?

Let me suggest, first of all, some patterns and developments in higher education that will be as viable in the 1980 s as they have been in the past. For example, advanced professional training. One may argue-I would argue - that the education of future doctors, dentists, engineers, lawyers, and public and private managers needs to be broadened and humanized. But it is difficult to conceive of the world we know in the United States functioning without a higher education system that devotes a part of its energies to turning out specialized professional talent and leadership.

Second, and an overlap of point one, higher education has a key role in the production of new knowledge and in social and aesthetic criticism. I have faith that the public support for these functions will continue into the $1980 \mathrm{~s}$ - even though recent DNA controversies have raised once again the question of whether the truth will make us free or will kill us all and even though the critical functions of a higher academy are a painful hair shirt for any society to wear.

Third, higher education performs and will continue to perform a custodial function for youth who would otherwise be unemployed. Compared to the provision of jobs through public works, colleges and universities are marvelously inexpensive holding tanks for an inadequately responsive market economy. My guess is that this function will be as valued in the 1980 s as it has been in the past.

These three functions-advanced professional training, new knowledge and criticism, and custodial-have great lasting power. The only trouble is that the first two involve only a tiny fraction of the academic enterprise and the last, as stated, conveys an image of a lost world in which zombied youth wander around without joy or purpose.

To pretend that such a mindless limbo can be transmuted into sudden significance by gearing all college courses to the cogs of first jobs in the largely routinized adult labor market is among the great illusions of the decade. Putting all of this in another way, if we need higher education only to train a limited cadre of professionals and critics, the existing academy is overexpanded by two-thirds.

On the other hand, if colleges and universities are to be holding tanks and job trainers for the lackluster jobs of a highly rationalized economy, who needs most of what we presently offer? A semester or two in job-specific training, a good studentunion building with Ping-Pong tables and a bowling alley, and a goodly supply of spectator sports and beer parlors would surely suffice.

Either way, the education of elite professionals and critics or keeping large numbers of youth off the streets by training them for 
simple jobs suggests a higher education enterprise in the 1980s truncated by half in terms of staff and offerings.

\section{EDUCATION'S MISSION}

Last year in a small monograph called The Purposes of Education, ${ }^{1}$ I tried to suggest another way of thinking about our mission. As we look ahead to the world in the 1980s and beyond the societal demands for a professional and critical elite, we may question what higher education is useful for. What kind of world is ahead for our students, and what relationship should exist between our colleges and universities and that world?

Let me be bold by being conservativeby extrapolating existing existential realities into the near future.

First, most Americans born in the latter half of the twentieth century, if they take even reasonable care of themselves, will live substantially beyond the biblically allotted years of three-score and ten. Medical breakthroughs - especially in the treatment of heart disease, cancer, and stroke-are beginning to extend expectations of life well beyond the actuarial plateau that has been maintained for most of this century in the western world.

However brief this candle may seem when viewed by the eye of eternity, a life span of 75 to 80 years involves a massive 650,000 to 700,000 hours of being, which is a lot of existence but not necessarily a lot of being. Even if sleep is deducted, something close to a half-million waking hours will be experienced by most Americans over their life spans.

Although the details of existence for the individual are unpredictable and highly variegated, one proposition can be made with a probability approaching certitude: Everyone will experience changes-most of them highly predictable - in physical capabilities and psychological attitudes in the process of maturing and aging. This is the bedrock reality of the stages of development.

For adult Americans, a second proposition will have substantial universality: waking hours will be spent in shifting combinations of personal and family coping, work, and free-self activities. Over sixty years of adult life, as the days and seasons roll, these repetitive preoccupations along with sleep constitute for most people the bedrock reality of what I call in my book the "existential wheel."

Third, each person will live out stages of development and spin an "existential wheel" within the context of a series of political, economic, and social systems. These systems will determine to a great extent who will be employed; how goods and services will be distributed; the rate of inflation; the availability of health, educational, and recreational services; the noxiousness or felicity of urban life; the degree and stability of international order; and a host of other conditions that will directly affect the quality of individual lives. This is the bedrock reality of the enveloping polity.

We may next question what might occur if the diverse institutions and instruments that constitute our educational system should consciously address these bedrock realities with the following basic purposes in mind:

1. To help persons anticipate, and increase their capacity for creative engagements with, major predictable changes (physical and psychological) in their stages of development.

2. To help persons in their concentric communities to cope, to work, and to use their free time in ways that minimize neurotic anxiety and boredom and that maximize inner fulfillment and joyful reciprocities.

3. To help persons to learn the arts of affecting the enveloping polity in order to promote justice and to secure the blessings of liberty for others as well as for themselves.

\section{EDUCATION'S CONTRIBUTION}

The Purposes of Education is an attempt to explore ways in which the major educative instruments-formal and informal-in American society might relate more effectively than in the past to the bedrock realities of the stages of development, the "existential wheel," and the enveloping polity.

\section{Stages of Development}

On the first, the stages of development, I draw nourishment from the writings of Erik Erikson, Charlotte Bühler, and Carl Jung - and their more recent American fol- 
lowers and critics: Gould, Neugarten, Levinson, Houle, Havighurst-those who have worked on stages of the life cycle, especially the adult years. I attempt to line out some of the known traumas and deficiencies in each stage and try to suggest that one purpose of education is to help people to have creative engagements with the tensions and traps of each stage.

And what of the three waking components of the "existential wheel": coping, work, and the free self?

\section{Coping}

By coping, I refer to performing those biological functions, completing those logistical tasks, and wrestling with those psychic dissonances that accompany the very fact of being alive in a functioning sense.

Most adult Americans spend a substantial part of each week in the following kinds of activities: preparing food, eating it, and cleaning up afterwards; brushing teeth; going to the toilet; washing bodies and clothes; shopping; repairing machines (or having them repaired); paying bills; balancing accounts; banking; going to, or worrying about the need to go to, doctors, dentists, and lawyers; filling out insurance and tax forms; fulfilling mandatory, expected, or hoped-for roles vis-à-vis spouses, children, other relatives and intimates, the community, and the law; parrying the anguishes of self-image, illness, nuclear threats, and relationships with others and with the universe. These things go on whether one is employed or not, retired or not, married or single. They constitute for most people the very stuff of mundane existence.

Parts of the daily routine are psychically neutral, even pleasurable. For all too many, too much of the time, the coping segment of the existential wheel is sullen, frustrating, and anxiety-ridden.

I try to suggest how education might address the coping problems of peopleparticularly those associated with health, with consumerism, with psychological interactions, and with existential despair, so that day-to day coping becomes increasingly an exercise in mastery not in anxiety.

\section{Work}

My treatment of the concept of work re- minds us that of the half-million hours of conscious existence, fewer than ninety thousand hours-less than one-fifth of the total-will be spent "on the job," that is, working for paid remuneration. And unless there are substantial shifts in public policy, even these proportions will obtain for only two-thirds or less of the adult population between the ages of eighteen and sixty-five. An additional reality is that 80 percent of available new jobs in the United States can be manned by persons with a high school education and three weeks or less of training.

\section{The Free Self}

I try to suggest how educators might approach the subject of education for work in such a context, and I distinguish between jobs and work-work connoting a far richer notion of occupational activity than jobs. But I try to emphasize the importance of viewing work as only a fraction of waking existence and point, therefore, to the importance of education for coping and for the world of the free self.

My comments on the "free self" attempt to address the diversions and technological baubles that comprise our Klaxon culture and the pervasive phenomenon of boredom. I ask what education can and should do to nourish the lasting inner satisfactions of life: aesthetic, physical, moral, and intellectual.

I conclude my essay on the free self by suggesting that if we cannot, through education, improve the world of the free self, it makes little difference if the nuclear missiles fall, for the alternative is an endless melancholy, a sullen ennui-deaf to the song of the thrush, blind to the evening sky, and indifferent to the creative wonders of man's mind and hand.

\section{The Enveloping Polity}

Finally, I turn to education's relationship to the enveloping polity - to the disenchantments we acknowledge, the injustices we perpetrate, the confusions and bureaucratic strictures we endure, and to the romantic notions we conjure to take us out of all this. I try to point to directions, based I hope upon mature assumptions, in which our educational system might go if the political economy is ultimately to be made to 
function so that it enhances rather than diminishes the lives of individual citizens.

\section{RELEVANCE FOR LIBRARIES}

Now what has all this got to do with college and research libraries? Three things, I think.

First, it suggests that you review existing holdings and serials not only in terms of past priorities and the demands of current academic specializations but also in terms of their utility to the future lives of students: to their life cycle, to their work, to their capacity to cope, to their free self, and to the discharge of their civic obligations.

Second, it suggests that much of what presently goes on in our academic kaleidoscope-including in our college and research libraries-is in fact defensible. What is needed is an increased attention by both faculty and library staffs to the guidance of students as they try to put together courses of studies and browsing lists that can truly enhance the quality of their future lives.

Third, and closely related to the second point, it suggests that both you and your faculties must try to redress the present intellectual imbalance in our society: our propensity for the partial-our exorbitant academic taste for refined trivia.

This nation is in woefully short supply of people equipped to look at problems as a whole, at life as a whole, at the earth as a whole.

\section{A SENSE OF THE WHOLE}

Alas, without a sense of the whole, we have no way of evaluating the parts, no way of appraising the importance of the expert, no way of seeing that the fragmentation and the violence we lament in the world around us are but the mirror image of our own cluttered and frenetic psyches.

College and university education at its best is not designed to relieve life of its pain and uncertainty. It is designed to help people have creative engagements with adversity, to discover and draw upon the wellsprings of existential joy, and to recognize their common plight and their need for one another.

Perched on a whirling planet, blind to our origins, blind to our reasons for being, we wander between a desolate sense that we are bits of transient nothingness and a strange sense of the presence of ineffable innuendos of hope that mock our despair. Whatever the long-range fate of the universe, we have a continuing commitment in education to discover and transmit truths that are in fact fertile hypotheses about the reality, and the latent possibilities, of the existence we know and of the existence we can anticipate for our children and our children's children.

If we could really educate ourselves as faculty, as counselors, as librarians to perform that function well, to give all of our students in both their classes and their browsing a sense of hope and meaning and joy in the creative engagements of being alive, I should cease to worry about their future, your future, or my future.

\section{REFERENCE}

1. Stephen K. Bailey, The Purposes of Education (Bloomington, Ind.: Phi Delta Kappa Educational Foundation, 1976). 